\title{
PENERAPAN ASUHAN KEPERAWATAN PADA PASIEN NY "D” DENGAN DIABETES MELITUS TIPE 2 DALAM PEMENUHAN KEBUTUHAN NUTRISI DI RSUD LABUANG BAJI MAKASSAR
}

The Application Of Nursing Care To Patient "D" With Type 2 Diabetes Mellitus In Fulfilment Nutrition Needs At Labuang Baji Hospital Makassar

\author{
Cahyati, Rahmawati \\ Prodi Diploma III Keperawatan FKIK Universitas Muhammadiyah Makassar \\ E-mail rahmawatisaid75@gmail.com \\ Hp. 085396944273
}

\begin{abstract}
According to WHO, 70\% of total deaths in the world, 90-95\% of cases are Type 2 Diabetes (T2D), most of which can be prevented by improving lifestyle. Type 2 Diabetes sufferers in Southeast Asia increased by $84 \%$, namely 82 million people and it seems to have increased to 151 million people in 2045. The prevalence of T2D in Indonesia increased from $6.9 \%$ in 2013 to $8.5 \%$ in 2018, who are at risk of heart attack, stroke, blindness, kidney failure and death. This is due to lifestyle. Several studies have shown that T2D can prevent healthy eating patterns and dietary adjustments to maintain blood sugar levels. This study aims to describe nursing care in the patient Mrs. "D" with type 2 diabetes in meeting nutritional needs. The method used is descriptive (case study). The study was conducted from 12-15 June 2019 at Labuang Baji General Hospital Makassar. Data were analyzed by using the nursing approach process. The results of the study obtained data that support impaired nutritional needs and blood glucose instability, hair loss, dry and dull, conjunctival anaemic, there is a wound on the right leg that is difficult to heal, nails break easily, albumin, creatinine and haemoglobin decrease, polyphagy, polyuria, such as patients. weak and increased blood glucose and there is a wound on the right leg that is difficult to heal. The application of nursing care focuses on nutritional knowledge by involving family, nutritional management, health education on the nutritional status of low glycemic index and management of hypoglycemia and hyperglycemia. The results showed that the fulfilment of nutritional needs has improved, which based on diet and offering insulin can control GDS levels and increase albumin levels.
\end{abstract}

Keywords: Diet, Nutrition, Nursing care, Type 2 Diabetes

\begin{abstract}
ABSTRAK
Menurut WHO, 70\% dari total kematian di dunia, 90-95\% kasus adalah Diabetes Melitus Tipe 2 (DMT2) yang sebagian besar dapat dicegah dengan memperbaiki gaya hidup. Penderita DMT2 di Asia Tenggara meningkat $84 \%$, yaitu 82 juta jiwa dan diperkirakan mengalami peningkatan menjadi 151 juta jiwa pada tahun 2045. Prevalensi DMT2 di Indonesia meningkat dari 6,9\% pada tahun 2013 menjadi 8,5\% pada tahun 2018, yang beresiko terkena serangan jantung, strok, kebutaan, gagal ginjal dan kematian. Hal ini disebabkan oleh life style. Beberapa penelitian menunjukkan DMT2 dapat dicegah melalui diet sehat dan pengaturan pola makan untuk mempertahankan kadar gula darah. Penelitian ini bertujuan menggambarkan asuhan keperawatan pada pasien Ny "D" dengan DM Tipe 2 dalam pemenuhan kebutuhan nutrisi. Metode yang digunakan adalah metode deskriptif (studi kasus). Penelitian dilakukan dari tanggal 12-15 Juni 2019 di RSUD Labuang Baji Makassar. Data dianalisis dengan pendekatan proses keperawatan. Hasil dari penelitian didapatkan data yang mendukung gangguan kebutuhan nutrisi dan ketidakstabilan glukosa darah seperti rambut rontok, kering dan kusam, konjuntiva anemis, terdapat luka pada kaki kanan yang sukar sembuh, kuku mudah patah, albumin, kreatinin, eritrosit dan haemoglobin menurun, poliphagi, poliuria, pasien lemah dan glukosa darah meningkat serta terdapat luka pada kaki kanan yang sukar sembuh. Penerapan asuhan keperawatan berfokus pada pemantauan nutrisi dengan melibatkan keluarga, manajemen nutrisi, pendidikan kesehatan tentang status nutrisi indeks glikemik rendah serta manajemen hipoglikemia dan hiperglikemia. Hasil penelitian menunjukkan pemenuhan kebutuhan nutrisi mengalami perbaikan, dimana kepatuhan terhadap diet dan pemberian insulin dapat mengontrol kadar GDS dan meningkatkan kadar albumin.
\end{abstract}

Kata kunci : Asuhan Keperawatan, Diabetes Melitus Tipe 2, Glukosa darah, Nutrisi, Pola makan 


\section{PENDAHULUAN}

Diabetes Melitus Tipe 2 (DMT2) merupakan penyakit tidak menular yang prevalensinya cenderung meningkat. Peningkatan penderita diabetes melitus dikarenakan adanya perubahan pola makan, yaitu dari makanan tradisional yang sehat, tinggi serat, rendah lemak, rendah kalori ke konsumsi makanan mengandung kalori seperti karbohidrat sederhana, lemak, daging merah dan rendah serat (Azrimaidaliza, 2011 dalam Nurlina, 2018)

Menurut WHO, 70\% dari total kematian di dunia, 90-95\% kasus adalah Diabetes Melitus Tipe 2 sebagian besar dapat dicegah dengan memperbaiki gaya hidup. Mayoritas DMT2 disebabkan oleh kelebihan berat badan dan kurangnya aktivitas fisik. Gaya hidup atau life style dapat mempengaruhi kesehatan seseorang, salah satunya yaitu obesitas yang merupakan faktor terjadinya peningkatan DM Tipe 2 terutama di negara-negara berkembang (Sari, 2018).

Menurut International Diabetes Federation (IDF) edisi ke-8 tahun 2017 menyatakan bahwa di Amerika sekarang mangalami peningkatan sebanyak $62 \%$ penderita DM dengan 26 juta jiwa dan diperkirakan pada tahun 2045 sebanyak 42 juta jiwa, dan di Afrika juga terjadi peningkatan $156 \%$ yang mengalami penderita DM sebanyak 16 juta jiwa dan tahun 2045 diperkirakan akan mengalami peningkatan sebanyak 41 juta jiwa, sedangkan di Asia Tenggara angka penderita diabetes meningkat $84 \%$, dimana sekarang 82 juta jiwa menderita diabetes dan diperkirakan jumlah penderita diabetes mengalami peningkatan menjadi 151 juta jiwa pada tahun 2045.

Indonesia merupakan salah satu negara berkembang yang memiliki angka kejadian DM Tipe 2 yang cukup tinggi. Jumlah penderita DM Tipe 2 pada tahun 2010 mencapai 8,4 juta jiwa dan diperkirakan pada tahun 2030 akan mengalami sebanyak 21,3 juta jiwa (Wild et al, 2004 dalam Haskas, 2017).

Di Sulawesi-Selatan menurut infodatin Kemenkes RI (2014) mengemukakan bahwa dari jumlah penduduk usia $>14$ tahun sebanyak 5.738.932 jiwa, angka penderita DM yang didiagnosis oleh dokter sebanyak 1,6\% dengan perkiraan 91.823 jiwa, namun yang belum terdiagnosa sebanyak $1,8 \%$ dengan perkiraan 103.301 jiwa, tetapi sering mengalami gejala sering lapar, sering haus, sering buang air kecil dengan jumlah banyak dan berat badan turun.

Berdasarkan hasil penelitian Fachruddin, et al. (2013), Turoan, et al. (2018) salah satu penyebab meningkatnya penyakit DM Tipe 2 adalah kurang patuh terhadap pola makan dan jadwal makan serta dipengaruhi oleh kurang informasi atau pengetahuan tentang diet.

Menurut PERKENI (Perkumpulan Endokrin Indonesia), penatalaksanaan Diabetes Melitus Tipe 2 terdiri atas empat pilar, salah satunya adalah terapi nutrisi atau perencanaan makanan (Widya \& Hartono, 2014). Sejalan dengan hasil penelitian Toharin, et al. (2015); Wahyuni dan Hermawati (2017) mengatakan bahwa kebutuhan nutrisi pada penderita diabetes merupakan kebutuhan fisiologi yang mendasar. Dimana asupan nutrisi atau makanan merupakan sumber utama gula darah bagi tubuh sehingga sangat berperan penting pada pasien DM Tipe 2 mengatur pola makan untuk mencapai dan mempertahankan kadar gula darah yang normal. Dalam perencanaan pola makanan sangat ditekankan diet dalam hal $3 \mathrm{~J}$ (jadwal makan, jenis makan dan jumlah makan), apabila pasien melakukan pola makan dan diet dengan teratur maka dapat mengontrol gula darah dan mencegah terjadinya komplikasi penyakit DM (PERKENI, 2011 dalam Hestiana, 2017).

Hal tersebut sejalan dengan hasil penelitian Almaini dan Heriyanto (2019); Azrimaidaliza (2011); Basri, et al. (2018) bahwa orang yang menjalankan diet atau mengatur pola makan dengan teratur dapat menjadikan glukosa darah dalam tubuh menjadi normal dibandingkan orang yang tidak menjalankan diet, seperti diet makanan yang mengandung rendah indeks glikemik (IG) yang akan memperbaiki glukosa darah, vitamin $C$ yang berperan sebagai anti oksidan akan menurunkan resistensi insulin melalui perbaikan fungsi endthelial dan menurunkan stres oksidatif sehingga mencegah berkembangnya kejadian DM tipe 2, serta penderita yang mengalami status gizi baik lebih cenderung mengalami proses penyembuhan yang baik.

Menurut Infodatin Kemenkes RI (2014), penyakit DM Tipe 2 yang tidak segera ditangani, dapat mengakibatkan meningkatnya resiko penyakit jantung dan stroke, Neuropati (kerusakan saraf) seperti amputasi kaki, retinopati diabetik dapat menyebabkan kebutaan, gagal ginjal, serta resiko kematian dua kali lipat dibandingkan dengan bukan penderita DM.

Berdasarkan fenomena tersebut di atas, penulis tertarik untuk melakukan penelitian studi kasus yang berjudul asuhan keperawatan pada pasien Diabetes Melitus Tipe 2 dalam pemenuhan kebutuhan nutrisi agar dapat diperoleh gambaran penerapan asuhan keperawatan dalam pemenuhan kebutuhn nutrisi khusunya tentang pengaturan pola diet dan pembatasan nutrisi pada penderita DM Tipe 2 dalam mengontrol glukosa darah untuk mencegah terjadi komplikasi. Selain itu, diharapkan pasien DMT2 dapat melakukan upaya mandiri dalam penatalaksanaan perawatan di rumah untuk meningkatkan kualita hidup.

\section{METODE}

Desain, tempat dan waktu

Desain penelitian menggunakan metode 
deskriptif dengan pendekatan studi kasus untuk mendeskripsikan asuhan keperawatan dalam pemenuhan kebutuhan nutrisi. Data dikumpulkan dengan metode wawancara, observasi, pemeriksaan fisik dan dokumentasi menggunakan instrumen pedoman wawancara, lembar observasi dan lembar ceklist. Data dianalisis dengan pendekatan proses keperawatan mulai dari pengkajian, diagnose keperawatan, perencanaan, implementasi dan evaluasi

Tempat penelitian dilaksanakan di Ruang Interna Baji Pa'mai RSUD Labuang Baji Makassar, dari tanggal 12-15 Juni 2019.

\section{Jumlah dan cara pengambilan subjek}

Populasi penelitian adalah semua pasien DMT2 yang dirawat di Ruang Interna Baji Pa'mai, dimana subjek yang digunakan dalam penelitian ini sebanyak satu orang pasien yang mengalami diabetes melitus tipe 2. Partisipan diperoleh dengan cara memilih subjek berdasarkan kriterian inklusi yaitu mengalami gangguan nutrisi, gula darah abnormal (GDS $\geq 200 \mathrm{mg} / \mathrm{dl}$ dan atau GDP $\geq 126 \mathrm{mg} / \mathrm{dl}$ dan atau GD 2 jam PP $\geq 200 \mathrm{mg} / \mathrm{dl}$ dan atau TTGO $\geq 200$ ), pasien dengan GDS normal namun mendapatkan terapi insulin, dirawat inap di rumah sakit dan bersedia menjadi responden.

\section{HASIL}

Pasien berinitial Ny. D usia 75 tahun, jenis kelamin perempuan, pekerjaan IRT, dirawat di RS pada tanggal 30 Mei 2019. Hasil dari pengkajian diperoleh data keluhan utama nyeri pada kaki sebelah kanan yang mengalami luka, luka dikerumuni semut selama 3 hari, nafsu makan meningkat, banyak makanan, banyak kencing di malam hari, sering haus dan lapar, sering menambah makanan berupa nasi, sayur, gorengan, dan makanan yang manis-manis. Riwayat obesitas, kebiasaan makan di warung, DM lebih kurang 5 tahun dan riwayat operasi kaki kiri. Pasien terlihat gemuk, hasil antropometrik yaitu lingkar kepala $55 \mathrm{~cm}$, lingkar dada $95,5 \mathrm{~cm}$, lingkar lengan $26,5 \mathrm{~cm}$, lingkar abdomen $107 \mathrm{~cm}$, tinggi badan $158 \mathrm{~cm}$, IMT dan BB tidak dapat diukur karena pasien tidak bisa bangun. merasa lemah dan sulit bergerak, bibir dan muka pucat, conjungtiva anemis, rambut kering, rontok dan kusam serta distribusi tidak merata, penglihatan buram, kuku mudah patah, nyeri dan udem pada kaki dengan pintting edema positif 1 . Hasil biomedical sign ditemukan glukosa darah naik turun, GDS tanggal 2-6-2019 $300 \mathrm{mg} / \mathrm{dl}$, GD 2 jam PP $319 \mathrm{mg} / \mathrm{dl}$, GDS tanggal 4-6-2019 $232 \mathrm{mg} / \mathrm{dl}$, tanggal 5-6-2019 $160 \mathrm{mg} / \mathrm{dl}$, GD $2 \mathrm{jam}$ PP $182 \mathrm{mg} / \mathrm{dl}$, tanggal 6-6-2019 $258 \mathrm{mg} / \mathrm{dl}$, tanggal 7-6-2019 $193 \mathrm{mg} / \mathrm{dl}$, tanggal 8-6-2019 GDS $176 \mathrm{~m} / \mathrm{dl}$, GDP $181 \mathrm{~m} / \mathrm{dl}$, tanggal 9-6-2019 GDS $176 \mathrm{mg} / \mathrm{dl}$, tanggal 10-6-2019 GDS $114 \mathrm{mg} / \mathrm{dl}$, tanggal 11-6-2019 GDP $152 \mathrm{mg} / \mathrm{dl}$,
GD 2 jam PP 183 mg/dl, tanggal 12-6-2019 GDS 250 $\mathrm{mg} / \mathrm{dl}$, albumin 1,85, g/dl, $\mathrm{Hb} 11.7 \mathrm{gr} / \mathrm{dl}$ dan Kreatinin menurun $0,45 \mathrm{mg} / \mathrm{dl}$. Jenis diet rendah kalori tinggi protein, jumlah kalori $1900 \mathrm{kkal}$, frekuensi makan 3 kali 200 bubur saring, jus buah sekali sehari, dan susu diabetasol.

Berdasarkan data tersebut dtemukan diagnosa keperawatan ketidakseimbangan nutrisi kurang dari kebutuhan berhubungan dengan penyakit kronid (diabetes melitus tipe 2) dan ketidakstabilan glukosa darah berhubungan dengan resistensi insulin.

Perencanaan untuk mengatasi masalah kekurangan nutrisi berfokus pada mengidentifikasi faktor asupan nutrisi, pola makan, kemampuan menelan, kelainan rongga mulut, monitor mual dan muntah, asupan makanan, hasil laboratorium,ukur antropometris, manajemen nutrisi, bantu pasien makan jika tidak makan sendiri, berikan pendidikan kesehatan tentang status nutrisi. Rencana ini bertujuan agar nutrisi pasien kembali normal dengan kritria hasil : peningkatan status nutrisi, energi meningkat, tidak ada tanda-tanda malnutrisi. Sedangkan perencanaan masalah keperawatan ketidakstabilan kadar gulah darah berhubungan dengan resistensi insulin, berfokus pada identifikasi kemungkinan penyebab hiperglikemia, monitor kadar glukosa darah, anjurkan patuh terhadap diet, pemberian injeksi insulin. Rencana ini bertujuan agar glukosa darah pasien dapat terkontrol dengan kriteria hasil : glukosa darah dalam tubuh dalam batas normal, hemoglobin glikolisat dalam batas normal.

Semua rencana tindakan dilaksanakan dengan melibatkan pasien dan keluarga serta melakukan evaluasi proses dan evaluasi akhir untuk menilai efektivitas tindakan. Setelah dilakukan perawatan selama 4 hari, hasil evaluasi belum teratasi namun menunjukkan perbaikan adanya kerjasama keluarga dalam mengontrol pembatasan makanan tambahan pada pasien dan pasien patuh terhadap diet yang diberikan, pasien dan keluarga memahmi tanda dan gejala hipoglimeia dan hiperglikemia, GDS $179 \mathrm{mg} / \mathrm{dl}$. Selain itu pasien mendapatkan perencanaan lanjutan berupa tambahan suplemen vitamin A, B, C, fujimin, zink dan albumin $25 \%$ dan insulin injeksi 16 unit post prandial.

\section{PEMBAHASAN}

Berdasarkan hasil penelitian pada studi kasus yang terjadi pada $\mathrm{Ny}$ "D" didapatkan data sebagai berikut :

a. Nafsu makan meningkat, banyak kencing dan sering haus. Hal ini disebabkan karena pasien menderita penyakit DM Tipe 2 dengan kadar kadar gula darah pasien meningkat yaitu 250 $\mathrm{mg} / \mathrm{dl}$. Menurut Aini dan Aridiana (2016), Tarwoto et al. (2012), Wijaya dan Putri (2013), penderita DM tipe 2 terjadi peningkatan nafsu makan 
disebabkan terjadi resistensi insulin sehingga uptake glukosa sel menurun, sehingga terjadi kelaparan sel. Kelaparan sel memicu pemeahan cadangan makanan yang ada di di hati dan otot dipecah melalui proses glikolisis, glukoneogenolisis dan liposis untuk dijadikan sumber energi tubuh. Kondisi ini menyebabkan energi berkurang dan menstimulasi hipolamus (pusat lapar), sehingga nafsu makan meningkat. Sedangkan pasien banyak kencing dan merasa haus disebabkan oleh hiperglikemia yang menyebabkan menurunan ambang filtrasi glukosa oleh ginjal (batas ambang 160-180 mg/100ml). Akibatnya terjadi diuresis osmotik, sehingga sehingga terjadi poliuria (banyak kencing).

b. Pasien memiliki riwayat obesitas. Keluarga pasien mengatakan pasien mengalami kegemukan sebelum sakit. Hal tersebut sejalan dengan pendapat Aini dan Aridiana (2016) mengatakan salah satu faktor yang mempengaruhi terjadi DM tipe 2 adalah obesitas, dimana obesitas mengakibatkan sel-sel $\beta$ pankreas mengalami hipertropi sehingga akan berpengaruh terhadap penurunan produksi insulin. Hal ini sejalan dengan hasil penelitian Sari (2018) bahwa orang yang mengalami obesitas memiliki resiko penyakit DM lebih besar dibandingkan dengan penyakit lain, dimana sekitar $80 \%$ orang yang mengalami DM Tipe 2 adalah obesitas.

c. Albumin menurun $1.85 \mathrm{gr} / \mathrm{dl}$. Hal ini disebabkan makanan yang masuk kedalam tubuh tidak terserap oleh sel-sel tubuh, maka cadangan makanan seperti protein dipecahkan untuk dijadikan energi, sehingga terjadi kekurangan protein, yang ditandai dengan rambut pasien rontok, distribusi tidak merata dan kusam. Hal ini sejalan dengan pendapat Tarwoto dan Wartonah (2015), bahwa nutrisi yang kurang dapat menyebabkan albumin menurun.

d. Haemoglobin rendah 11,7 g/dl. Pada pasien didapatkan data konjungtiva anemis, bibir pucat, muka pucat. Hal tersebut disebabkan protein yang ada didalam tubuh dipecah untuk dijadikan sebagai energi. Akibatnya proses pembentukan sel darah merah berkurang yang berakibat pada rendahnya kadar haemoglobin ada di dalam untuk membawa oksigen keseluruh tubuh, sehingga terjadi anemia.

e. Kreatinin menurun $0,45 \mathrm{mg} / \mathrm{dl}$. Penderita DM tipe 2 mengalami kekurangan nutrisi atau protein di dalam tubuh, sehingga massa otot menghasilkan kadar rendah limbah kimia (kreatinin). Menurut Haryono dan Susanti (2019), ureum atau kreatinin bisa saja meningkat atau mungkin dalam kondisi normal, ada juga dehidrasi atau terjadi penurunan fungsi ginjal. f. Rambut rontok, distribusi rambut tidak merata, dan kusam, konjuntiva anemis dan pasien memgatakan penglitannya sudah buram. Hal tersebut terjadi karena kurangnya nutrisi yang ada didalam tubuh ditandai dengan albumin pasien rendah, haemoglobin rendah. Hal ini sejalan dengan pendapat Aini dan Aridiana (2016), mengatakan bahwa pada pasien DM sering di jumpai seperti rambut mudah rontok dan tipis, mata menjadi katarak dan mengalami menjadi kabur atau buram. Hal ini sejalan dengan pendapat Tarwoto et al. (2012) mengatakan pada kondisi kronis, keadaan hiperglikemia menyebabkan aliran darah menjadi lambat, sirkulasi ke vaskuler tidak lancar termasuk pada mata yang dapat merusak retina serta kekeruhan pada lensa.

g. Kuku pasien mudah patah. Menurut Tarwoto \& Wartonah (2015) mengemukakan bahwa pada pemeriksaan fisik didapatkan kuku mudah patah pada pasien yang mengalami kekurangan nutrisi.

h. Pasien mengatakan lemah. Hal ini didapatkan pada pasien yang hanya berbaring ditempat tidur namun pasien mengatakan merasa lemah dan sulit bergerak. Sejalan dengan pendapat Haryono dan Susanti (2019), mengatakan bahwa pada pola aktifitas pasien sering ditemukan seperti gejala lemah dan sulit bergerak. Kurangnya cadangan energi, adanya kelaparan sel, kehilangan energi sehingga mengakibatkan pasien mudah lelah dan letih (Tarwoto et al., 2017).

i. Jenis diet pasien rendah karbohidrat tinggi protein dengan jumlah kalori 1900 kkal. Pasien menderita DM tipe 2 dengan kondisi kekurangan nutrisi seperti penurunan albumin, rambut mengalami rontok dan lain-lain dan juga mengalami peninggkatan gula darah, sehingga diberi diet rendah karbohidrat tinggi protein. Hal tersebut didukung oleh Sunita (2010) dalam Juhartini (2017) bahwa dalam penentuan diet yang diberikan kepada pasien tergantung dari keadaan pasien, status gizi, jenis diabetes yang diderita pasien.

Berdasarkan data tersebut di atas dan hasil analisa data ditemukan dua masalah yaitu ketidakseimbangan nutrisi kurang dari kebutuhan tubuh berhubungan dengan penyakit kronis (Diabetes Melitus tipe 2). Menurut Wilkinson (2016) bahwa faktor yang berhubungan dengan ketidakseimbangan nutrisi kurang dari kebeutuhan tubuh adalah penyakit kronis (Diabetes Melitus Tipe 2). Masalah kedua yaitu ketidakstabilan kadar glukosa darah dalam tubuh berhubungan dengan resistensi insulin. Menurut Standar diagnosa keperawatan Indonesia (2017) bahwa faktor yang berhubungan dengan ketidakstabilan glukosa darah dalah resistensi insulin. 
Perencanaan masalah keperawatan ketidakseimbangan nutrisi kurang dari kebutuhan tubuh berhubungan dengan penyakit Diabetes Melitus Tipe 2 berfokus pada mengidentifikasi faktor yang mempengaruhi asupan gizi, pola makan, kemampuan menelan, kelainan rongga mulut, monitor mual dan muntah, asupan makanan, hasil laboratorium,ukur antropometris, manajemen nutrisi, bantu pasien makan jika tidak makan sendiri, berikan pendidikan kesehatan tentang status nutrisi. Rencana ini bertujuan agar nutrisi pasien kembali normal dengan kritria hasil : peningkatan status nutrisi, energi meningkat, tidak ada tanda-tanda malnutrisi.

Sedangkan perencanaan masalah keperawatan ketidakstabilan kadar gulah darah berhubungan dengan resistensi insulin, berfokus pada identifikasi kemungkinan penyebab hiperglikemia, monitor kadar glukosa darah, anjurkan patuh terhadap diet, pemberian injeksi insulin. Rencana ini bertujuan agar glukosa darah pasien dapat terkontrol dengan kriteria hasil : glukosa darah dalam tubuh dalam batas normal atau terkontrol, hemoglobin glikolisat dalam batas normal.

Implementasi keperawatan dilakukan sesuai rencana dari setiap masalah. Implementasi ketidakseimbangan nutrisi kurang dari kebutuhan tubuh berhubungan dengan penyakit Diabetes Melitus Tipe 2, yaitu:

a. Memantau nutrisi

1.Mengidentifikasi faktor yang mempengaruhi asupan gizi. Hal ini kita mengontrol makan klien. Menurut Tarwoto dan Wartonah (2015), menyatakan bahwa beberapa faktor yang mempengaruhi kekurangan nutrisi penting diidentifikasi dasar tindakan selanjutnya.

2.Mengidentifikasi pola makan. Hal ini dapat membantu pasien untuk mengatur jenis, jumlah jadwal makan pasien. Menurut Deokes (2009), pola makan merupakan cara dalam mengatur jumlah dan jenis asupan makanan dengan maksud untuk mempertahankan kesehatan dan status gizi, serta mencegah atau membantu proses penyembuhan. Hal tersebut didukung oleh hasil penelitian Susanti dan Bistara (2018), bahwa pengaturan pola makan pada penderita DM sangatlah penting karena jika tidak dianjurkan maka akan terjadi ketidakstabilan glukosa darah.

3.Mengidentifikasi kebutuhan kalori dan jenis nutrisi. Hal ini akan lebih mempermudah dalam pemantau diet yang diberikan. Menurut Sunati, (2010) dalam Juhartini (2017), mengatakan bahwa jenis diet yang diberikan kepada pasien tergantung oleh keadaan pasien. Kebutuhan energi tiap penderita DM juga berbeda-beda tergantung pada status gizi pasien.
4.Mengidentifikasi kemampuan menelan. Hal ini dapat membantu dalam pemberian nutrisi, dimana jika pasien tidak dapat menelan makanan dengan baik, maka asupan makanan pasien akan terganggu. Menurut Kozier dan Erb (2009), mengatakan bahwa jika pasien mengalami kesulitan menelan (disfagia) dapat mempengaruhi asupan makanan yang tidak adekuat.

5.Mengidentifikasi kelainan rogga mulut. Hal ini dapat membantu untuk mengetahui apakah ada kelainan atau masalah pada mulut. Seperti pada hasil penelitian Emor, Pandaki dan Supit ( 2015), mengatakan bahwa periodontal atau infeksi pada gusi merupakan akibat dari tidak terkontrolnya kadar gula darah.

6.Memonitor mual dan muntah. Hal ini perlu dilakukan karena untuk mengidentifikasi gangguan asupan makanan, sehingga memudahkan dalam merencanakan upaya tindak lanjut. Menurut Kozier dan Erb (2009), mengatakan bahwa mual dan muntah dapat mempengaruhi asupan makanan yang tidak adekuat atau pencernaan dan absorbsi makanan yang tidak benar.

7.Memonitor asupan makanan. Hal ini dapat mengontrol asupan makanan apakah ada makanan tambahan atau makanan yang diberikan dihabiskan atau tidak. Hal ini didukung oleh Paruntu, 2012 dalam Amanina, et al. (2015), mengatakan bahwa memonitor asupan makanan pada penderita DM tipe 2 sangatlah penting, karena asupan makanan (karbohidrat) yang berlebihan akan menyebabkan gula darah dalam tubuh meningkat. sehingga memiliki resiko besar untuk tidak dapat mengendalikan kadar glukosa darah dalam tubuh.

8.Memonitor hasil laboratorium. Dalam memantau hasil laboratorium perawat bisa mengetahui bahwa ada perubahan terhadap nutrisi pasien. Sesuai dengan pendapat Kozier B, et al. (2010), bahwa pemeriksaaan laboratorium merupakan pengkajian nutrisi sebagai data objektif yang digunakan untuk memprediksi atau mengukur derajat resiko masalah nutrisi.

9.Mengukur antropometri. Pengukuran antropometri dapat membantu dalam menentukan apakah terjadi kekurangan nutrisi atau kelebihan nutrisi. Sejalan dengan pendapat Suparisa, et al. (2002), bahwa status gizi dapat didefenisikan sebagai ekspresi dari keadaan keseimbangan antara konsumsi dan penyerapan zat gizi dan penggunaan zat gizi tersebut. Beberapa dari indeks antopometri yang dapat digunakan untuk mengukur status gizi yaitu pengukuran indeks massa tubuh 
(IMT), pengukuran lingkar lengan atas, dan pengukuran lingkar pinggang.

b. Memanajemen nutrisi. Menganjurkan pasien mengonsumsi vitamin C. Menurut Ardekani, aet al. (2007) dalam Azrimaidaliza (2011), bahwa vitamin C merupakan sumber utama dari bahan makan alami seperti sayur-sayuran dan buah-buahan. Jika dikonsumsi sesuai dengan kebutuhan dapat memberikan manfaat dalam mencegah terjadinya penyakit degeneratif. Hal tersebut sejalan dengan pendapat Azrimaidaliza (2011), bahwa peran vitamin $C$ dapat menurunkan resistensi insulin melalui perbaikan fungsi endothelial dan menurunkan stress oksidatif sehingga mencegah terjadinya DM tipe 2.

c. Membantu pasien makan jika tidak dapat makan sendiri. Membantu makanan kepada pasien sangat penting apalagi kepada pasien yang sudah lansia dan lemah tidak mampu makan sendiri. Kozier B, et al. (2010) mengatakan bahwa dua kelompok yang sering kali memerlukan bantuan untuk makan, seperti: lansia yang lemah dan orang cacat seperti tuna netra, mereka yang harus tetap dalam posisi terlentang, atau mereka yang tidak dapat menggunakan tangannya. Dengan ini rencana asuhan keperawatan pasien akan mengindikasikan bantuan saat makan.

d. Memberikan pendidikan kesehatan tentang status nutrisi pasien. Pendidikan kesehatan mengenai nutrsi pasien agar pasien mengetahui kondisi nutrisi sekarang dan kooperatif dalam pemantauan nutrisi, sehingga pasien diharapkan patuh terhadap diet yang diberikan. Hal tersebut didukung oleh hasil penelitian Hestiana (2017), menyatakan bahwa penderita yang memiliki pendidikan yang tinggi akan mempunyai pengetahuan yang luas dan lebih patuh dalam menjalani diet dari pada penderita tingkat pengetahuan yang menengah.

e. Memberikan pendidikan kesehatan tentang nutrisi seperti makanan rendah indeks glikemik. Hal ini akan menambah wawasan pasien dan keluarga dalam mengatur dan menyediakan makanan rendah indeks glikemik sehingga dapat membantu pasien dalam menurunkan gula darah. Sejalan dengan pendapat Azrimaidaliza (2011), makanan yang mengandung tinggi IG (indeks glikemik) dapat menyebabkan kenaikan glukosa darah. Oleh karena itu dianjurkan kepada pasien untuk mengonsumsi makanan yang rendah IG seperti sayur-sayuran (bayam, kangkung), buah-buahan (apel, salak) dan kacang-kacangan (kacang tanah, kacang merah), dengan mengkonsumsi diet rendah IG dapat memperbaiki kadar gula darah.

f. Memberikan edukasi kepada pasien dan keluarga pasien makanan yang dianjurkan untuk dikonsumsi dan makanan yang dihindari. Hal ini dapat membantu kepatuhan dalam pola makan pasien dan dapat mencegah terjadinya peningkatan kadar gula darah dalam tubuh. Sejalan dengan hasil penelitian Fachruddin, et.al. (2013), bahwa banyak responden yang tidak patuh terhadap pola makan karena tidak mendapatkan edukasi tentang pola makan. Menurut Jauhari dan Nasution (2013), bahan makanan yang dianjurkan untuk penderita DM yaitu makanan yang bersumber dari karbohidrat, seperti : nasi, kentang, ubi. Makanan yang bersumber dari protein rendah lemak, seperti : ikan, ayam tanpa kulit, tempe, tahu dan kacangkacangan. Adapun makanan yang harus dihindari yaitu : makanan yang mengadung banyak gula, seperti : gula pasir, gula jawa, sirup, makanan yang mengandung banyak lemak, seperti : cake dan makanan siap saji (fast food), serta gorenggorengan, makanan yang mengandung banyak natrium, seperti : ikan asin, telur asin, makanan yang diawetkan.

g. Melakukan kolaborasi pemberian vitamin dengan tim medis. Vitamin merupakan suplemen untuk memenuhi kebutuhan nutrisi pasien dan juga dapat membantu dalam penyembuhan luka. Menurut hasil penelitian Soep dan triwibowo (2015), bahwa pasien yang nutrisinya terpenuhi akan lebih cepat proses penyembuhan lukanya. Misalnya nutrisi dengan mengonsumsi diet tinggi protein, vitamin A, C, B12, Zat besi, dan Kalsium dapat mengalami penyembuhan luka. Jika terjadi malnutrisi, maka proses penyembuhan luka terhambat dan dapat mengalami terjadi infeksi.

h. Mengatur posisi pasien semifowler pada saat makan. Posisi semifowler pada saat makan memberi rasa nyaman, mengurangi distensi abdomen dan mencegah terjadi aspirasi makanan pada saluran pernafasan. Menurut Tarwoto dan Wartonah (2015), bahwa mengatur posisi semifowler saat makan dapat menghindari aspirasi atau gangguan pernapasan dan juga mengurangi distensi abdomen.

Implementasi ketidakstabilan kadar gula darah berhubungan dengan resistensi insulin, yaitu melakukan manajemen hiperglikemia

a. Mengidentifikasi kemungkinan penyebab hiperglikemia. Tindakan ini sebagai upaya antisipasi dini terjadinya hiperglikemia untuk rencana tindak lanjut. Umum kenaikan gula darah terjadi karena pasien tidak mengontrol pola makan. Menurut Fatimah (2015), peningkatan diabetes melitus dipengruhi oleh beberapa faktor seperti, pola makan, obesitas, kurang aktivitas dan lain-lain.

b. Menganjurkan monitor kadar glukosa darah. Memantau glukosa darah merupakan hal penting 
karena perawat dapat mengetahui perubahan gula darah pasien apakah terkontrol atau malah sebaliknya. Hal ini didukung oleh hasil penelitian Khasma, et al. (2016) bahwa tindakan pemeriksaan gula darah secara rutin sangat efektif dan dapat menangani masalah ketidakseimbangan nutrisi dan gangguan insulin pada penderita DM.

c. Menganjurkan patuh terhadap diet. Memotivasi pasien agar patuh terhadap diet dapat membantu dalam mengontrol gula darah dalam tubuh. Menurut Purwanto (2011) dalam Juhartini (2017), bahwa kepatuhan dalam diet yang dilakukan merupakan salah satu cara untuk menstabilkan kadar gula dalam darah menjadi normal dan dapat mencegah komplikasi. Hal ini didukung oleh hasil penelitian Toharin, et al. (2015) bahwa jika pasien patuh terhadap diet, maka dapat mengontrol kadar gula darah kalien.

d. Memonitor tanda dan gejala hiperglikemia. Tanda dan gejala hiperglikemia dapat mengetahui adanya fluktuasi kadar gula darah dalam tubuh pasien, sehingga memudahkan dalam upaya tindak lanjut. Menurut Gibney, et al. (2008) dalam Putri dan Isfandiari (2013), menyatakan bahwa tanda dan gejala hiperglikemia umumnya banyak berkemih (poliuria), banyak minum (polidipsia), dan banyak makan (polifagia) dengan penurunan berat badan. Namun jika nutrisi dan glukosa darah tidak dikontrol, hal ini dapat berakibat coma diabetikum

e. Memberikan penjelasan kepada pasien dan keluarga pasien tentang tanda dan gejala hipoglekemia dan hiperglikemia. Menurut teori Tjokoprawiro, et al (2015), tanda dan gejala hipoglekemia yaitu muka pucat, berkeringat dingin, gangguan kognitif, kejang, koma, gemetar,cemasdan glukosa darah kurang dari 60 $\mathrm{mg} / \mathrm{dl}$. Adapun terapi hipoglekemia yaitu glukosa 15-20 (2-3 sendok makan) yang dilarutkan dalam air, jika pemantauan pemantauan gula mandiri setelah 15 menit pengobatan, hipohlekemia masih ada maka pengbatan dilanjutkan, namun jika kadar gula darah sudah normal, pasien diminta untuk makan makanan yang berat atau snak untuk mencegah berulangnya hipoglkemia. Adapun tanda dan gelaja hiperglikemia menurut Fox dan Klivert (2010) yaitu haus, urin berlebihan, mual, nyeri perut, banyak makan, kulit memerah dan kering, tidak sadar, penurunan berat badan. Adapun penatalaksanaan menurut Fatimah (2015), yaitu dengan memodifikasi gaya hidup seperti melakukan diet, terapi insulin, dan olah raga secara teratur.

f. Memberikan injeksi insulin. Injeksi insulin kepada pasien dapat meningkatkan ambilan glukosa oleh sel sebagai sumber energi. Menurut Fatimah
(2015), mengatakan bahwa DM tipe 2 yang sudah memburuk, penggantian insulin total menjadi kebutuhan. Insulin merupakan hormon yang mempengaruhi metabolisme karbohidrat maupun metabolisme protein dan lemak. Fungsi insulin antara lain menaikkan pengambilan glukosa ke dalam sel-sel sebagian besar jaringan, menaikkan penguraian glukosa secara oksidatif, menaikkan pembentukan glikogen dalam hati dan otot serta mencegah penguraian glikogen, menstimulasi pembentukan protein dan lemak dari glukosa. Sejalan dengan hasil penelitian Rasyid, et al. (2019), bahwa dalam pemberian injeksi insulin pada pasien lebih efektip ketika diberi insulin pada waktu 0-10 menit sebelum makan.

Setelah dilakukan tindakan keperawatan selama 4 hari, masalah ketidakseimbangan nutrisi kurang dari kebutuhan tubuh belum teratasi. Namun pasien menunjukkan perbaikan dimana keluarga pasien mengatakan pasien selalu minta makanan namun tidak diberikan, pasien memahami alasan pembatasan diet, pasien patuh terhadap diet, pasien makan 3xsehari dan dihabiskan. Makan pagi berupa bubur saring campur 1 butir telur dan susu diabetasol sebanyak $38 \mathrm{sdm}$, makan siang berupa bubur saring sebanyak $19 \mathrm{sdm}$ dengan bahan nasi, wortel, tempe, ikan dan susu diabetasol, pasien minum jus buah semangka 1xsehari dan dihabiskan, pasien dibantu dalam pemberian makanan melalui oral, pasien minum susu diabetasol sebanyak 1 xsehari dan dihabiskan, pasien nampak patuh terhadap diet yang diberikan, pasien diberi vitamin $A, B, C$, zink, dan fujimin, albumin $25 \%$,

Sedangkan masalah ketidakstabilan glukosa darah belum teratasi namun menunjukkan perbaikan perilaku berupa keluarga pasien mengatakan tidak ada makanan tambahan yang diberikan kepada pasien, pasien dan keluarga pasien paham tentang tanda hipoglekemia dan hiperglikemia dan tindakan yang harus dilakukan jika hal tersebut terjadi, nilai GDS $179 \mathrm{mg} / \mathrm{dl}$, nilai albumin meningkat $2.15 \mathrm{gr} / \mathrm{dl}$, pasien patuh terhadap diet, tetap mendapat injeksi insulin 16 unit setiap sebelum makan. Hal tersebut sesuai dengan hasil penelitian Toharin, et al. (2015), bahwa jika pasien patuh terhadap diet yang diberikan maka dapat mengontrol gula darah pasien, seperti patuh terhadap jumlah kalori, jenis makanan dan jadwal makanan yag sudah ditentukan.

\section{KESIMPULAN}

Pada pengkajian ditemukan data-data yang mendukung gangguan pemenuhan kebutuhan nutrisi berupa data antropometri, biomedical sign, clinical sign dan dietary history sehingga diangkat dua diagnosa keperawatan yaitu ketidakseimbangan 
nutrisi kurang dari kebutuhan tubuh dan ketidakstabilan glukosa darah. Perencanaan disusun berfokus pada manajemen nutrisi berupa pengaturan pola diet, pembatasan diet dan pengontrolan kadar glukosa darah. Semua perencanaan dilaksanakan dengan melibatkan pasien dan keluarga dengan memodifikasi sesuai kondisi pasien tiap hari. Hasil evaluasi menunjukkan pasien mengalami perbaikan, dimana pembatasan diet, kepatuhan terhadap diet dan pemberian insulin dapat mengontrol kadar GDS dan meningkatkan kadar albumin.

\section{SARAN}

Diharapkan kepada perawat agar mengkaji lebih mendalam tentang riwayat dan kebiasaan pola diet pasien sebagai dasar dalam menentukan diet yang tepat sesuai kebutuhan pasien. Selain itu, perawat perlu lebih ketat dalam pemantauan pembatasan diet dan pola makan pasien selama dirawat dengan melibatkan keluarga pasien dalam penatalaksaan perawatan di rumah sakit serta memberikan discharge planning tentang penatalaksanaan dan pembatasan diet di rumah selama 24 jam dan mengontrol glukosa darah pasien di pelayanan kesehatan.

\section{UCAPAN TERIMA KASIH}

Terima kasih kami ucapkan kepada Direktur RSUD Labuang Baji Makassar, khususnya perawat di Ruangan Interna Baji Pa'mai atas bantuan dan kerjasamany selama penelitian.

\section{DAFTAR PUSTAKA}

Aini, N., \& Aridiana, L. M. (2016). Asuhan Keperawatan SISTEM ENDOKRIN dengan pendekatan NANDA NIC-NOC. Jakarta: Selemba Medika.

Almaini, \& Heriyanto, H. (2019). Pengaruh Kepatuhan Diet, Aktivitas Fisik dan Pengobatan dengan Perubahan Kadar Gula Darah Pada Pasien Diabetes Melitus Seku Rejang. Jurnal keperawatan raflesia, volume 1 nomor 1 , Mei 2019 ISSN : 2656-6222, DOI 10.33088/jkr.vlil.393 http://jurnal.poltekkes-kemenkesbengkulu.ac.id/index.php/jkr, 66-65. Diakses 14 Mei 2019

Amanina, A., Raharjo, B., \& N, F. S. (2015). Hubungan asupan karbohidrat dan serat dengan kejadian Diabetes Melitus Tipe Il di wilayah kerja puskesmas Puwosari Surakarta. Artikel penelitian, 1-10. Diakses 15 Mei 2019.

Arsianti, R. W., Alexander, A., Mulyadi, \& Raudah. (2019). Rancangan Bangun Alat Ukur Indeks Massa Tubuh untuk Deteksi Diabetes Melitus Tipe 2. J-Eltrik, Vol. 1, No. 1 , Juli 2019 http://dx.doi.org/10.30649/je.v I i l.16, 1-6. Diakses 15 Mei 2019.

Azrimaidaliza. (2011). Asupan Zat Gizi dan Penyakit Diabetes Melitus. Jurnal Kesehatan masyarakat, Vol.6, No.1. Diakses 10 Maret 2019.

Bararah, T., \& Jauhar, M. (2013). Asuhan Keperawatan Panduan Lengkap Menjadi Perawat Profesional . Jakarta: Prestasi Pustaka.

Basri, H. M., Harun, \& Rahmatia, S. (2018). Hubungan status nutrisi dan kecemasan dengan proses penyembuhan luka diabetes melitus di ruang rawat inap bedah Rsud Barru. Jurnal ilmiah kesehatan diagnosis volume 12 nomor 5, 476-481. Diakses 6 April 2019.

Dharma, K. K. (2011). Metodologi Penelitian Keperawatan (Pedoman Melaksanakan dan Merapatkan Hail Penenlitian). Jakarta Timur: CV. Trans Info Media.

F.Emor, S., Pandaki, K., \& Supit, A. S. (2015). Hubungan Status Peroidontal Dan Derajat Regulasi Gula Darah Pasien Diabetes Melitus di Rumah Sakit Umum Pusat Prof DR.R.DKanduo Manado. jurnal e-GiGi (eG), volume 3, nomor 1, 210-215. Diakses 01 juli 2019

Fachruddin, I. I., Citrakesumasari, \& Alharin, S. (2013). Upaya penanganan dan perilaku pasien penderita Daibetes Melitus Tipe 2 di Puskesmas Bara-Barayya Kota Makassar. 1-13. Diakses 6 April 2019.

Fatimah, R. N. (2015). Diabetes Melitus Tipe 2. J Majority volume 4 Nomor 5, 93-101.

Fitriani, L. I., Murbawani, E. A., \& Nissa, C. (2018). Hubungan Asupan Vitamin C, Vitamin E, dan B karoten dengan kadar gula darah puasa pada wanita usia 35-50 tahun. juournal of nutrition collage, 85. Diakses 13 Maret 2019. 
Jurnal Media Keperawatan: Politeknik Kesehatan Makassar

Vol. 11 No. 22020

e-issn : 2622-0148, p-issn : 2087-0035

Fox, C., \& Klivert, A. (2010). Bersahabat dengan diabetes melitus . Jakarta: Niaga Swadaya.

Haryono, R., \& Susanti, B. A. (2019). Asuhan keperawatan pada pasien dengan gangguan sistem endokrin. Yogyakarta: PT. Pustaka Baru.

Haskas, Y.. (2017). Determinan Perilaku Pengendalian Diabetes Melitus di Wilayah Kota Makassar. Global Health Science, Volume 2 Issue 2, Juni 2017, 138-144. Diakses tanggal 15 April 2019

Herdman, T., \& Kamitsuru, S. (2015). Diagnosis Keperawatan. Jakarta: Kedokteran EGC.

Heriana, P. (2014). Kebutuhan Dasar Manusia. Tangerang Selatan: Binarupa Aksara.

Hidayat, A. A., \& Uliyah, M. (2012). Kebutuhan Dasar Manusia . Surabaya: Health Books.

Idris, A. M., Jafar, N., \& Indriasari, R. (2014). Pola makan dengan kadar gula darah pasien DM tipe 2. MKMI, 211-218. Diakses 16 April 2019.

Jauhari, A., \& Nasution, N. (2013). Nutrisi \& Keperawatan. Yogyakarta: Jaya IImu.

Kozier, \& Erb. (2009). Buku Ajar Praktik Keperawatan Klinis. Jakarta: EGC.

Kozier, B., Erb, G., Berman, A., \& Snyder, S. J. (2010). Fundamental Keperawatan. Jakarta: EGC.

Maulana, M. (2009). Mengenal Diabetes Melitus panduan praktris menangani penyakit kencing manis. jogjakarta: KataHati.

Nurarif, A. H., \& Kusuma, H. (2015). Asuhan Keperawatan NANDA NIC-NOC. Jogjakarta: Mediaction.

Nurlina. (2018). Penerapan Asuhan Keperawatan pada Pasien Ny. N dengan DM Tipe Il dalam Pemenuhan Kebutuhan Nutrisi di RSUD Labuang Baji Makassar. Jurnal Media Keperawatan Volume 9 No. 2. DOI: https://doi.org/10.32382/jmk.v9i1, 63-81. Diakses tanggal 20 April 2019.

PPNI, T. P. (2017). Standar Diagnosis Keperawatan Indonesia. Jakarta Selatan: DPP PPNI.

PPNI, T. P. (2018). Standar Intervensi Keperawatan Indonesia. Jakarta Selatan: DPP PPNI.

Purwanti, P. H. (2010). Diet Sehat Tanpa Lapar. Jakarta Selatan: Transmedia Pustaka.

Putri, N. H., \& Isfandiari, M. A. (2013). Hubungan Empat Pilar Pengendalian DM Tipe 2 Dengan Rerata Kadar Gula Darah. Jurnal berkala Epidemiologi, Vol.1, No.2 Sepetember 2013, 234-243. Diakses 15 April 2019.

Rasyid, W., Nur, B. M., Irawati, D., \& Rayasari, F. (2019). Efektifitas Waktu Injeksi Insulin Terhadap Kadar Glukosa Darah 2 Jam Setelah Makan Pada Pasien Diabetes Melitus. Jurnal Keperawatan Silampari (JKS) Volume 2, Nomor 2. DOl: https://doi.org/10.31539/jks.v2i2.502, 39-52. Diakses tanggal 20 Juli 2019.

Rendy, M. C., \& TH, M. (2012). Asuhan Keperawatan Medikal Bedah dan Penyakit Dalam. Yogyakarta: Nuha Medika.

Sari, N. N. (2018). Hubungan Obesitas Sentral dengan Kejadian Diabetes M elitus Tipe 2. Jurnal IImia Keperawatan Sai Betik, Volume 14, No.2 , 157-161. Diakses 16 April 2019.

Susanti, \& Bistara, D. N. (2018). Hubungan Pola Makan Dengan Kadar Gula Darah pada Penderita Diabetes Melitus. Jurnal Kesehatan Vokasional J Kes V http://journal.ugm.ac.id/jkesvo, 2599-3275. Diakses tanggal 20 April 2019.

Sutandi, A. (2012). Self Manajement Education (DSM) sebagai Metode Alternatif dalam Perawatan mandiri Pasien Diabetes Melitus Di Dalam Keluarga. Kesehatan, 54-59. Diakses 15 April 2019.

Tarwoto, \& Wartonah. (2015). Kebutuhan Dasar Manusia Dan Proses Keperawatan Edisi 5. jakarta: Salemba Medika. 
Tarwoto, Wartonah, Taufiq, I., \& Muliyati, L. (2012). Keperawatan Medikal Bedah Gangguan Sistem Endokrin. Jakarta Timur: CV. Trans Info Media.

Tjokoprawiro, A., Setiawan, P. B., Santoso, D., Soegiarto, G., \& Rahmawati, L. D. (2015). Buku Ajar Ilmu Penyakit Dalam. Surabaya: Airlannga University Pres (AUP).

Toharin, S. N., Cahyati, W. H., \& Zainafree, I. (2015). Hubungan modifikasi gaya hidup dan kepatuhan konsumsi obat antidiabetik dengan kadar gula darah pada penderita Diabetes Melitus Tipe 2 di Rs Qim batang tahun 2013. Unnes Journal Of Public Health http://journal.unnes.ac.id/sju/index.php/ujph, 153-160. Diakses 16 April 2019.

Wahyuni \& Hermawati. (2017). Persepsi pemenuhan kebutuhan nutrisi pada Pasien Diabetes Melitus di Desa Sawah Kuwung Karang Anyar. journal care vol. 5, No. 2, 306-317. Diakses 16 Maret 2019.

Widya, R. I., \& Hartono, A. (2014). Sehat dengan Gaya Hidup Terapi Gisi Medik untuk Berbagai Penyakit. yogyakarta: Rapha publishing.

Wijaya, A. S., \& Putri, Y. M. (2013). KMB 2 Keperawatan Medikal Bedah (Keperawatan Dewasa). yogyakarta: Nuha Medika.

Wilkinson, J. M. (2016). Diagnosis Keperawatan. Jakarta: EGC.

Yuniati, R., Pradigdo, S. F., \& Rahfiludin, M. Z. (2017). Hubungan Konsumsi Karbohidrat, Lemak Dan Serat Dengan Kadar Glukosa Darah Pada Lanjut Usia Wanita (Studi di Rumah Pelayanan Sosial Lanjut Usia Pucang Gading Kota Semarang. Jurnal Kesehatan Masyarakat (e-Journal) Volume 5, Nomor 4, http://ejournal3.undip.ac.id/index.php/jkm , 759-767. Diakses tanggal 31 maret 2019. 